\title{
Clostridium difficile and its cytotoxin in infants admitted to hospital with infectious gastroenteritis
}

\author{
M E ELLIS, B K MANDAL, E M DUNBAR, K R BUNDELL
}

\begin{abstract}
During a prospective study of infectious gastroenteritis in children under 2 years, 19 out of 390 patients (4.9\%) were found to have Clostridium difficile cytotoxin in the faeces. In several there was no history of use of antibiotics. The symptoms of many infants with toxin settled spontaneously, but one child became acutely and severely ill and developed a toxic megacolon and five others required, and responded to, vancomycin.

Cl difficile was cultured from the stools in $191(49 \%)$ of the children. The highly significant increased prevalence of past use of antibiotics in 118 control patients was not associated with an increased incidence of either isolation of $\mathrm{Cl}$ difficile or presence of faecal cytotoxin.

Cl difficile should not be overlooked as a cause of acute diarrhoea and vomiting in children under 2 years.
\end{abstract}

\section{Introduction}

Clostridium difficile is a well established cause of sporadic diarrhoea in adults. Usually the condition is associated with use of antibiotics but it may occur spontaneously. ${ }^{12}$ The organism is detectable in up to half of all healthy infants, and occasionally its cytotoxin may be found in infants in the absence of symptoms. ${ }^{3}$ In certain circumstances a devastating illness with florid pseudomembranous colitis occurs, which may prove fatal. ${ }^{4}$

We decided to culture stools routinely for the organism and to screen for the toxin as part of a prospective study of children admitted with infectious gastroenteritis over a 12 month period; full details of the prospective study are reported separately ${ }^{5}$ (M E Ellis, Barbara Watson, B K Mandal et al, to be published).

\section{Subjects and methods}

During December 1981 to November 1982, 447 children aged under 2 years were admitted to the Regional Infectious Diseases Unit, Monsall Hospital, with infectious gastroenteritis. A detailed questionnaire was administered verbally to the mother within 24 hours of admission. In particular details of antibiotic administration within the previous two months were recorded.

A total of 118 children under 2 years with non-gastrointestinal illness admitted over the same period served as a control group.

Samples of faeces obtained on admission were cultured for bacteria and viruses, and electron microscopy for viruses was also performed; techniques were as described (Ellis $e t$ al, to be published).

Testing of faeces for $\mathrm{Cl}$ difficile cytotoxin-Approximately $1 \mathrm{~g}$ of faeces was emulsified in $4 \mathrm{ml}$ faecal transport medium and centrifuged

Regional Department of Infectious Diseases and Tropical Medicine, Monsall Hospital, Manchester M10 8WR

M E ELLIS, MRCP, senior registrar

B K MANDAL, FRCP, consultant physician

E M DUNBAR, MRCP, consultant physician

Public Health Laboratory, Withington Hospital, Manchester M20 8LR

K R BUNDELL, BSC, FIMLS, senior MLSO

Correspondence to: Dr M E Ellis. at $3000 \mathrm{rpm}$ for 15 minutes. The supernatant $(0 \cdot 1 \mathrm{ml})$ was inoculated on to a monolayer of MRC 5 fibroblasts in a tube containing $0.8 \mathrm{ml}$ fibroblast maintenance medium. The tubes were incubated at $37^{\circ} \mathrm{C}$ and examined for the characteristic cytopathic effect at 24 and 46 hours. The specificity of the cytotoxin was confirmed by neutralisation with antiserum prepared against $\mathrm{Cl}$ sordellii toxin. Dilutions of the toxic supernatant were prepared and inoculated on to two sets of MRC 5 fibroblasts as above. A standard dilution of $\mathrm{Cl}$ sordellii antitoxin $(0 \cdot 1 \mathrm{ml})$ was added to one set of tubes. After 24-48 hours of incubation at $37^{\circ} \mathrm{C}$ the tubes were examined for cytotoxin. A positive result was accepted when the cytopathic effect was totally neutralised when the same dilution of test material was incubated with $\mathrm{Cl}$ sordellii antitoxin.

Isolation and detection of $\mathrm{Cl}$ difficile-Faeces were inoculated directly on to agar plates containing $\mathrm{Cl}$ difficile agar base (Oxoid; CM601), $10 \%$ defibrinated horse blood, and cycloserine $500 \mathrm{~g} / \mathrm{l}$ and cefoxitin $16 \mathrm{~g} / \mathrm{l}$. Faeces were also enriched for $\mathrm{Cl}$ difficile by inoculation into cooked meat medium (Lab M). Cooked meat cultures were incubated for three days at $37^{\circ} \mathrm{C}$, heated to $80^{\circ} \mathrm{C}$ for 10 minutes (to kill all nonsporulating bacteria), reincubated for three days at $37^{\circ} \mathrm{C}$, and then subcultured to $\mathrm{Cl}$ difficile agar. Isolated colonies were subcultured to blood agar to confirm purity and then to cooked meat medium and incubated at $37^{\circ} \mathrm{C}$ for three days. Identification of $\mathrm{Cl}$ difficile was by gas-liquid chromatography of the volatile fatty acids produced in cooked meat medium. Supernatants of the cooked meat cultures were also checked for toxin production on MRC 5 fibroblasts (in vitro toxin). Centrifugation of the test material was not necessary.

Statistical analysis - The standard $\chi^{2}$ test of Fisher's exact test was used for two dimensional tables. For three dimensional tables log linear models were used to examine interactions between three variables. Contingency tables were used.

\section{Results}

$\mathrm{Cl}$ difficile and its cytotoxin were looked for in the stools of 390 of the 447 children admitted with gastroenteritis and the 118 controls. Of these children, $191(49 \%)$ with gastroenteritis and $39(33 \%)$ of the controls had positive cultures for $\mathrm{Cl}$ difficile (table I).

Nineteen patients $(4.9 \%)$ in the gastroenteritis group and three of the controls $(2.5 \%)$ had faecal cytotoxin associated with toxigenic organisms (tables I and II). Thirteen patients with gastroenteritis had other micro-organisms, mostly rotaviruses or adenoviruses (table II). Antibiotics had been prescribed for 14 of the 19 patients within the preceding two months for illnesses such as otitis media and tonsillitis; the drugs used were mainly amoxycillin and cephalosporins (table III). All three controls had received treatment with antibiotics.

Although the course of the illness in the toxin positive cases was generally mild and comparable to that in the gastroenteritis group overall, six patients were treated with vancomycin because of the severity of their illness. All had severe and prolonged diarrhoea, and two also had severe abdominal features which in one case progressed to toxic megacolon (figure). (This patient was case 1 in the series reported by Mandal et al..$^{6}$ ) All were treated with oral vancomycin (the last patient received intravenous metronidazole in addition) and showed a prompt response, the faecal cytotoxin disappearing during convalescence.

TABLE I-Incidence of detection of $\mathrm{Cl}$ difficile and faecal cytotoxin

\begin{tabular}{|c|c|c|}
\hline & $\begin{array}{l}\text { Controls } \\
(n=118)\end{array}$ & $\begin{array}{c}\text { Patients } \\
(\mathrm{n}=390)\end{array}$ \\
\hline $\begin{array}{l}\text { No }(\%) \text { from whom } \mathrm{Cl} \text { difficile isolated } \\
\text { No }(\%) \text { with history of antibiotic use } \\
\text { No }(\%) \text { in whom toxin detected }\end{array}$ & $\begin{array}{l}39(33 \cdot 0)^{*} \\
77(65 \cdot 0) \dagger \\
3(2 \cdot 5)^{*}\end{array}$ & $\begin{array}{r}191(49 \cdot 0)^{*} \\
79(20 \cdot 0)^{\dagger} \\
19(4 \cdot 9)^{*}\end{array}$ \\
\hline
\end{tabular}

* Difference not statistically significant.

$\dagger$ Difference highly significant $(\mathrm{p} \ll 0.001)$ 
TABLE II-Details of patients with positive assay result for $\mathrm{Cl}$ difficile faecal cytotoxin

\begin{tabular}{|c|c|c|c|c|c|c|c|c|c|}
\hline & $\begin{array}{l}\text { No of } \\
\text { subjects }\end{array}$ & $\begin{array}{c}\text { Mean age in } \\
\text { months (SD) } \\
\text { [range] }\end{array}$ & $M: F$ & $\begin{array}{l}\text { No with } \\
\text { associated } \\
\text { micro- } \\
\text { organisms }\end{array}$ & $\begin{array}{l}\text { No with } \\
\text { history of } \\
\text { antibiotic } \\
\text { use }\end{array}$ & $\begin{array}{c}\text { Mean No of } \\
\text { days of } \\
\text { diarrhoea }(\mathrm{SD}) \\
\text { [range] }\end{array}$ & $\begin{array}{c}\text { Mean No of } \\
\text { days of } \\
\text { vomiting }(\mathrm{SD}) \\
\text { [range] }\end{array}$ & $\begin{array}{l}\text { Mean No of } \\
\text { days of } \\
\text { stay (SD) } \\
\text { [range] }\end{array}$ & $\begin{array}{l}\text { No with } \\
\text { white cell } \\
\text { count } \\
>13 \times 10^{8} / 1\end{array}$ \\
\hline $\begin{array}{l}\text { Patients with gastroenteritis: } \\
\text { Recovered spontaneously } \\
\text { Required vancomycin } \\
\text { Control patients }\end{array}$ & $\begin{array}{r}13 \\
6 \\
3+\end{array}$ & $\begin{array}{c}6 \cdot 6(5 \cdot 5)[1-24] \\
7 \cdot 6(6 \cdot 1)[1-15] \\
13 \cdot 3(4 \cdot 0)[11-18]\end{array}$ & $\begin{array}{l}6: 7 \\
3: 3 \\
3: 0\end{array}$ & $\begin{array}{c}10^{*} \\
3^{*} \\
0\end{array}$ & $\begin{array}{l}9 \dagger \\
5 \dagger \\
3 \$\end{array}$ & $\begin{array}{r}6 \cdot 9(7 \cdot 1)[2-28] \\
15 \cdot 0(5 \cdot 1)[9-18]\end{array}$ & $\begin{array}{l}5 \cdot 5(7 \cdot 1)[0-28] \\
6 \cdot 7(8 \cdot 2)[0-21]\end{array}$ & $\begin{array}{c}6 \cdot 6(2 \cdot 2)[4-12] \\
18 \cdot 7(3 \cdot 1)[14-23]\end{array}$ & $\begin{array}{l}4 \\
5\end{array}$ \\
\hline
\end{tabular}

* Rotavirus $(n=5)$; adenovirus $(n=6)$; Escherichia coli $018(n=1)$; calicivirus $(n=1)$; Coxsackie virus A9 $(n=1)$.

+ None $(n=5)$; erythromycin $(n=2)$; amoxycillin $(n=5)$; streptomycin $(n=1)$; penicillin $(n=1)$; cephalosporin $(n=4)$; ampicillin $(n=1)$.

Control patients: chickenpox + mastoiditis + bronchitis $(n=1)$; tonsillitis $(n=1)$; whooping cough + otitis media + pneumonia $(n=1)$.

$\$$ Co-trimoxazole + ampicillin + flucloxacillin + erythromycin + fusidic acid $(n=1)$; ampicillin, two courses $(n=1)$; co-trimoxazole for three weeks $(n=1)$.

Of the remaining 172 cytotoxin negative but culture positive patients in the gastroenteritis group, $129(75 \%)$ had toxigenic and 43 $(25 \%)$ non-toxigenic organisms. Of the remaining 36 controls, 19 $(54 \%)$ had toxigenic and $17(46 \%)$ non-toxigenic organisms. There were no significant clinical differences between the culture positive and culture negative groups, and within the culture positive group the presence of toxigenicity was not associated with any specific illness or a more severe illness.

Despite the greater use of antibiotics in the control group, the incidence of positive $\mathrm{Cl}$ difficile isolation was in fact less in this group (table I). Erythromycin was used two and a half times more frequently in the control group as opposed to a two and a half fold greater use of penicillins and co-trimoxazole by the gastroenteritis group (table III). Table IV shows the detailed analysis for groups more closely matched for age.

TABLE III-Antibiotic usage (expressed as percentage of antibiotics used)

\begin{tabular}{lccccc}
\hline & Erythromycin & $\begin{array}{c}\text { Ampicillin/ } \\
\text { amoxycillin/ } \\
\text { penicillin }\end{array}$ & Co-trimoxazole & Others & $\begin{array}{c}\text { All } \\
\text { antibiotics }\end{array}$ \\
\hline $\begin{array}{l}\text { Used by } \\
\text { controls (") }\end{array}$ & 57 & 30 & 1 & 12 & 100 \\
$\begin{array}{c}\text { Used by patients } \\
\text { with gastro- } \\
\text { enteritis \% }\end{array}$ & 21 & 48 & 30 & 1 & 100 \\
\hline
\end{tabular}

\section{Discussion}

Our finding that 19 children with diarrhoea (4.9\%) had $\mathrm{Cl}$ difficile cytotoxin in the faeces gives an incidence comparable to that of established pathogens such as enteropathic Escherichia coli (6.9\%), Campylobacter jejuni (5.1\%), Salmonella spp $(4 \cdot 3 \%)$, and Shigella spp $(2 \%),{ }^{5}$ which suggests that it may be an important cause of community acquired infantile gastroenteritis. The presence of other micro-organisms (mainly viruses) in 13 of these 19 children makes it difficult to assess the individual contribution that each of these organisms makes to the illness, although the severity of the clinical features and the prompt response to the appropriate treatment in six patients strongly suggest a dominant pathogenic role for $\mathrm{Cl}$ difficile. A synergistic role between more than one micro-organism is a possible but unproved mechanism. Perhaps past viral infection renders conditions in the gastrointestinal tract more suitable for production of toxin. Liquid in the intestine may encourage

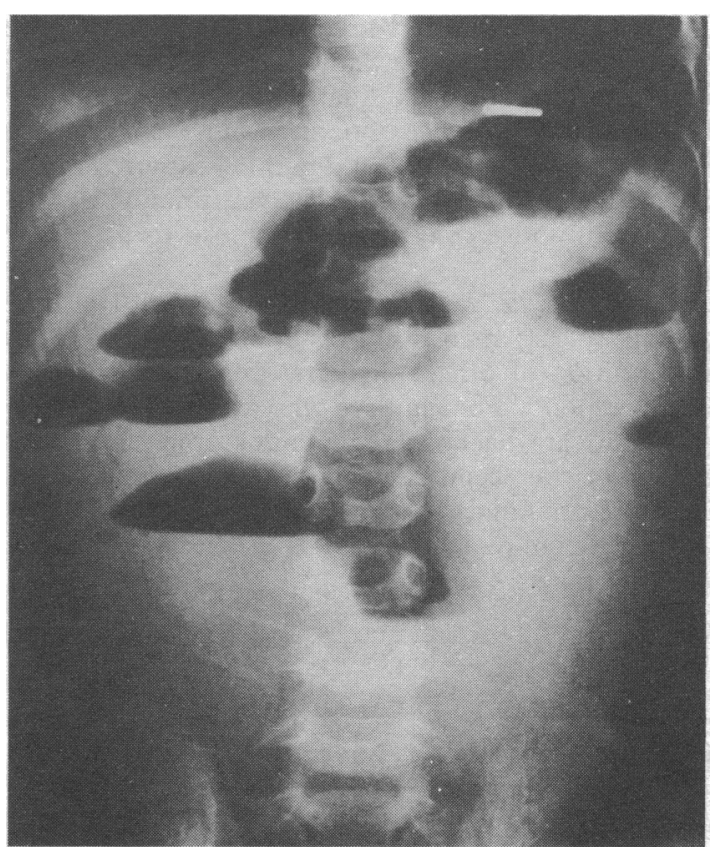

Plain abdominal radiograph (erect) in case of severe pseudomembranous colitis showing dilated loops of large intestine with multiple fluid levels.

proliferation and toxin production, and the recent findings in patients with inflammatory bowel disease suggest that this may be so. ${ }^{7}$ The problem of multiple microbial isolation is not peculiar to the $\mathrm{Cl}$ difficile group and was an interesting feature of our study; for example, $83 \%$ of patients with campylobacters also had other pathogenic micro-organisms present (Ellis et al, to be published), illustrating the impossibility of ascertaining the dominant role of any particular pathogen in most such cases.

The absence of a clear history of antibiotic usage in six of the 19 cytotoxin positive patients emphasises the importance of routine screening for $\mathrm{Cl}$ difficile toxin in all cases of infantile diarrhoea, so that its presence may not be overlooked and potential catastrophes as a result of inappropriate treatment may be averted. ${ }^{4}$

TABLE IV-Association of Cl difficile isolation with antibiotic usage. (Results for group aged 7-18 months which for controls and patients showed best age distribution match)

\begin{tabular}{|c|c|c|c|c|c|c|c|c|}
\hline & \multicolumn{4}{|c|}{ Controls } & \multicolumn{4}{|c|}{ Patients } \\
\hline & $\begin{array}{l}\text { No negative } \\
\text { for } \mathrm{Cl} \text { difficile }\end{array}$ & $\begin{array}{l}\text { No positive } \\
\text { for Cl difficile }\end{array}$ & Total & $\begin{array}{l}\% \text { positive for } \\
\text { Cl difficile }\end{array}$ & $\begin{array}{l}\text { No negative } \\
\text { for } \mathrm{Cl} \text { difficile }\end{array}$ & $\begin{array}{l}\text { No positive } \\
\text { for } \mathrm{Cl} \text { difficile }\end{array}$ & Total & $\begin{array}{l}\text { \% positive for } \\
\text { Cl difficile }\end{array}$ \\
\hline \multirow{2}{*}{$\begin{array}{l}\text { Patients given antibiotics } \\
\text { Patients not given } \\
\text { antibiotics }\end{array}$} & 30 & 13 & 43 & $30 \cdot 0$ & 27 & 16 & 43 & $37 \cdot 0$ \\
\hline & 13 & 5 & 18 & $28 \cdot 0$ & 87 & 63 & 150 & $42 \cdot 0$ \\
\hline $\begin{array}{l}\text { Total } \\
\% \text {, given antibiotics }\end{array}$ & $\begin{array}{l}43 \\
70 \cdot 0\end{array}$ & $\begin{array}{l}18 \\
72 \cdot 0\end{array}$ & $\begin{array}{c}61 \\
71 \cdot 0^{*}\end{array}$ & $29 \cdot 0$ & $\begin{array}{l}114 \\
24 \cdot 0\end{array}$ & $\begin{array}{l}79 \\
20 \cdot 0\end{array}$ & $\begin{array}{l}193 \\
22 \cdot 0^{*}\end{array}$ & $41 \cdot 0$ \\
\hline
\end{tabular}

* Significance of difference in antibiotic usage: $\mathrm{p} \ll 0.001$; all other differences including percentage of patients with $\mathrm{Cl}$ difficile on culture not significant. 
Up to half of the children in our study had $\mathrm{Cl}$ difficile isolated from the stool with no associated faecal toxin; this has been noted before. The absence of any clinical differences between those who do and those who do not have the organism (and whether toxigenic or non-toxigenic in vitro) and a similar incidence of isolation of the organism among controls support the notion that the presence of $\mathrm{Cl}$ difficile alone and without demonstrable faecal toxin is not primarily pathogenic.

The lesser incidence of the organism in our control group despite a threefold increase in antibiotic usage is of interest and confirms the findings of the Swedish group who found that $\mathrm{Cl}$ difficile occurred numerically more often in children who had not been treated by antibiotics than in those who had been given such drugs. ${ }^{8}$ This may be related to the more frequent use of the antianaerobic antibiotic erythromycin in the controls. Alternatively children who have gastroenteritis may be more prone to $\mathrm{Cl}$ difficile associated diarrhoea and colitis. Thus other microorganisms are found in three quarters of patients (Ellis et al, to be published); the incidence of toxin in our gastroenteritis group was twice that of the controls; and parallel experience from adult cases suggests that disturbance in bowel function due to causes other than antibiotics may also predispose to $\mathrm{Cl}$ difficile diarrhoea. ${ }^{2}$

The role of $\mathrm{Cl}$ difficile cytotoxin in children with gastroenteritis is not totally clear; many recover spontaneously, whereas the clinical condition of others demands treatment, to which they apparently respond. For children who are not that ill guidelines for treatment are lacking. Sigmoidoscopic and histological appearances of the rectal mucosa may be normal (especially if the disease is proximal) or non-specific; and toxin titres often bear little relation to severity of the disease. In view of the disastrous consequences of failure to treat some cases ${ }^{4}$ it seems prudent to treat all children who have symptoms and toxin in the stool with at least five days of oral vancomycin.

We are most grateful to D M Jones, director of the Public Health Laboratory, Withington, for his generous contribution of the use of the laboratory facilities in this study. We also thank Sisters M Coyle, $\mathrm{N}$ Fosbrook, and $\mathrm{S}$ Thompson and the nursing staff of the paediatric wards at Monsall Hospital for their efficient and untiring contribution in making the study run smoothly. Mr Andrzej Makowski, of the department of statistics, North West Regional Health Authority, gave expert help with the statistical data.

\section{References}

${ }^{1}$ Brettle RP, Poxton IR, McMurdoch J, et al. Clostridium difficile in association with sporadic diarrhoea. Br Med f 1982;284:230-3.

${ }^{2}$ Ellis ME, Watson B, Milewski PJ, Jones G. Clostridium difficile colitis unassociated with antibiotic therapy. Br f Surg 1983;70:242-3.

${ }^{3}$ Rietra PJGM, Slaterus KW, Meuwissen SGM, Zanen HC. Clostridial toxin in faeces of healthy infants. Lancet 1978;ii:319.

4 Richardson SA, Brookfield DSK, French TA, Gray J. Pseudomembranous colitis in a 5-week-old infant. Br Med $\mathcal{F} 1981 ; 283: 1510$.

5 Ellis ME, Watson B, Mandal BK, et al. Contemporary gastroenteritis of infancy: clinical features and prehospital management. Br Med f 1984; 288:521-3.

- Mandal BK, Watson B, Ellis ME. Pseudomembranous colitis in a 5-weekold infant. Br Med F 1982;284:345-6.

7 Greenfield C, Aguilar-Ramirez JR, Pounder RE, et al. Clostridium difficile and inflammatory bowel disease. Gut 1983;24:713-7.

${ }^{*}$ Holst E, Helin I, Per-Anders M. Recovery of Clostridium difficile from children. Scand $\mathcal{F}$ Infect Dis $1981 ; 13: 41-5$.

(Accepted 25 November 1983)

\title{
Analysis of T cell subsets in Graves' disease: alterations associated with carbimazole
}

\author{
MARIAN E LUDGATE, ALAN M MCGREGOR, ANTHONY P WEETMAN, \\ SUVINA RATANACHAIYAVONG, JOHN H LAZARUS, REGINALD HALL, \\ GORDON W MIDDLETON
}

\begin{abstract}
Conflicting data on subpopulations of peripheral blood lymphocytes in patients with autoimmune disease largely reflect variations in methods of study. An investigation was therefore conducted aimed at avoiding this difficulty.

Serial samples of peripheral blood mononuclear cells from 42 patients with hyperthyroid Graves' disease were collected at monthly intervals before, during, and for 12
\end{abstract}

\footnotetext{
Departments of Medicine and Medical Physics, Welsh National School of Medicine, Cardiff

MARIAN E LUDGATE, PHD, research associate

ALAN M MCGREGOR, MD, MRCP, Wellcome senior fellow and honorary consultant physician

ANTHONY P WEETMAN, MD, MRCP, lecturer in medicine

SUVINA RATANACHAIYAVONG, MD, research associate

JOHN H LAZARUS, MD, FRCP, senior lecturer and honorary consultant physician

REGINALD HALI, MD, FRCP, professor of medicine

GORDON W MIDDLETON, MSC, senior physicist
}

Correspondence to: Dr Alan M McGregor, Department of Medicine, Welsh National School of Medicine, Heath Park, Cardiff CF4 4XN. months after a six month course of carbimazole. Samples were stored in liquid nitrogen until completion of the study, when they were thawed and all samples from each patient analysed within the same assay using mouse monoclonal antibodies to human cell subsets and a fluorescence activated cell sorter. Proportions of cytotoxic/suppressor (OKT8) positive cells before treatment (mean 17.4 (SEM 0.8)\%) were significantly lower $(p<0.001)$ than those in normal controls $(29.8(1.9) \% ; n-10)$ and returned to normal by the end of treatment. In contrast, the proportions of activated $T$ cells (OKIa-OKM1) were significantly raised before treatment as compared with normal (14.4 (0.6)\% versus $4.6(0.8) \%$; $<<0.001)$ and fell to normal by the end of treatment. Proportions of OKT3 and OKT4 positive $T$ cells remained unchanged throughout treatment and in the succeeding 12 months. In patients who relapsed after treatment there was a rise in the proportion of activated $T$ cells and a fall in OKT8 positive $T$ cells, which returned towards normal with retreatment.

The explanation for the alterations in numbers of circulating $T$ cells remains to be determined but they may provide a means for predicting more accurately the outcome of Graves' disease after treatment with carbimazole. 